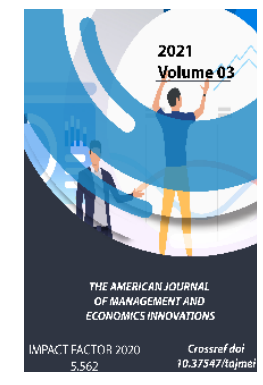

Journal Website: https://theamericanjou rnals.com/index.php/ta jmei

Copyright: Original content from this work may be used under the terms of the creative commons attributes 4.0 licence.

\section{Economic Geology And Its Development In Uzbekistan}

\section{J.J. Movlanov}

Director, Center Of Geoinnovation Technologies University Of Geological Sciences, Tashkent, Uzbekistan

Arofat Khaydarova

Student, University Of Geological Sciences, Tashkent, Uzbekistan

Navruzbek Jurabekov

Student, University Of Geological Sciences, Tashkent, Uzbekistan

\title{
ABSTRACT
}

This article analyzes the science of economic geology and the development of the geological economy in Uzbekistan. The material describes economic geology, its types, applications, and purpose. The article focuses on the results of the rating of the Republic of Uzbekistan on gold ( $\mathrm{Au}$ ) mining, its achievements, and its annual strategy.

\section{KEYWORDS}

Economic Geology, Coal, Building Stone, Non-Metallic Minerals, Oil, Precious And Base Metals, Water, Forbes World Gold Council, Turquoise, Arsenic, Kitcho.

\section{INTRODUCTION}

Economic geology is the study of fuels, metals, and other materials from the earth that are of interest to industry or the economy as a whole. It depends on the distribution of resources, the cost and benefits of restoring them, and the value and availability of available materials. These materials include minerals (rocks or minerals of economic value) and fossil fuels that contain a variety of products, from petroleum to coal.

Economic geology is concerned with land materials that can be used for economic and industrial purposes. These materials include precious and base metals, non-metallic minerals, and building stones. Economic 
geology is the lower discipline of geophysics. According to Lindgren (1933), this was the "application of geology". Today it can be called the scientific study of the Earth's mineral resources and the application of the acquired knowledge. The term usually refers to metal mineral deposits and mineral resources. Earth science can be used to understand, describe, and exploit a deposit using techniques used by other sciences (such as geochemistry, mineralogy, geophysics, petrology, and structural geology) [1].

\section{THE MAIN FINDINGS AND RESULTS}

The purpose of studying economic geology is to understand the genesis and localization of deposits and the minerals associated with them. Although metals, minerals, and other geological commodities cannot be restored in time, the impression of a permanent or limited shortage paradigm has always led to human innovation, and as a result, the commodity they replace has become very expensive. The main reserves of many minerals are very large (for example, copper in the earth's crust, if the current rate of consumption lasts more than 100 million years). Nevertheless, economic geologists continue to successfully expand and describe certain mineral resources.

Some sources in the geological sciences use a narrower definition of "economic geology" than is used here. Perhaps the development and geological environment will be improved by limiting non-mineral resources, including excess, primarily to a category consisting of fossil fuels, a more limited definition of minerals, and mineral economic geology [2]. Given the economic importance of fossil fuels such as oil and its by-products, coal and peat, it seems appropriate to discuss these valuable organic resources alongside valuable inorganic resources (Figure 1).

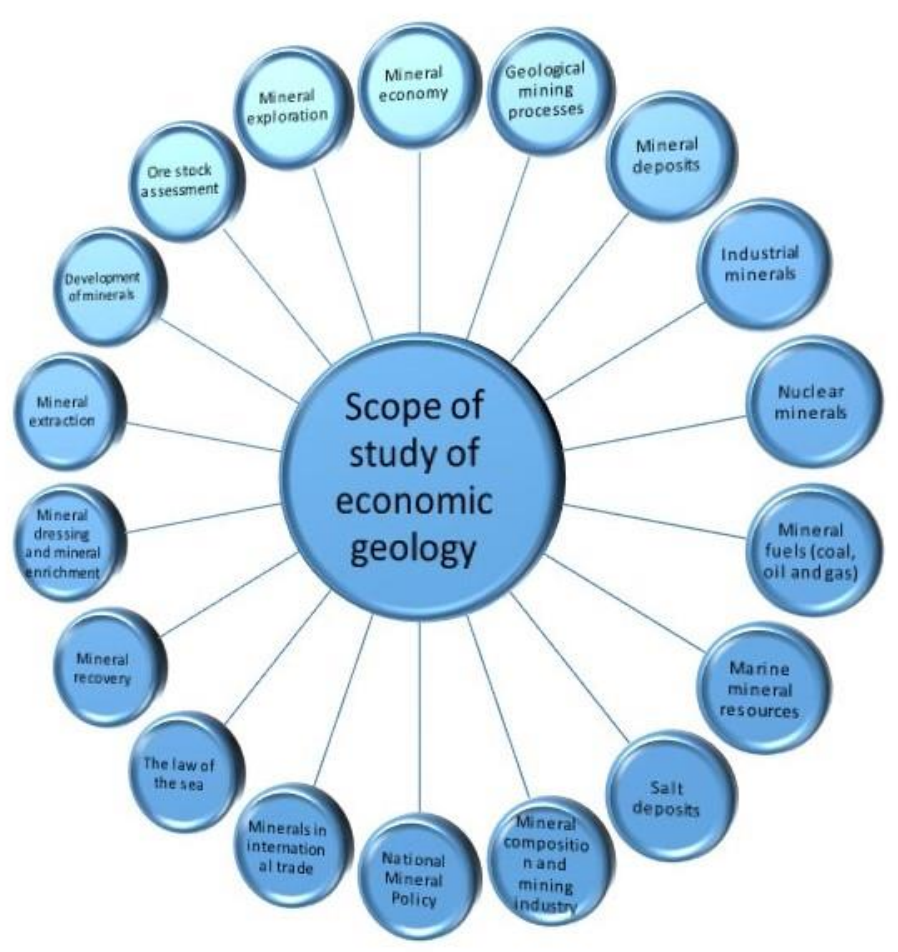

Figure 1. Areas of study of economic geology 
The concept of economic geology is relatively new, although people have been extracting precious metals and minerals from the earth since ancient times. Despite their ability to value such resources, modern people had almost no scientific theories about how they were formed or how they were produced.

The Greeks, for example, believed that the roots of metal objects on earth indicated that these materials were living things with roots, such as trees. Medieval astrologers say that each of the "seven planets" (the Sun, the Moon, and the five planets, in addition to what was known at the time) ruled over one of seven metals: gold, copper, silver, lead, tin, and iron. And mercury is thought to have been created under the influence of their "planets".

The Faculty of Science trains the next generation of scientists on the latest achievements in economic geology and other earth sciences.

The most commonly used minerals in research are:

- coal,

- $\quad$ Stone for construction,

- $\quad$ non-metallic minerals,
- $\quad$ petroleum minerals,

- $\quad$ precious and base metals and water.

Many of these resources are non-renewable, and scientists use innovative methods to find new deposits and other valuable materials to combat shortages.

Research in economic geology often covers other disciplines such as coal and oil geology (sedimentology), mining geology and genesis, mineralogy, structural geology, geochemistry, and geophysics [3].

The level of demand for gold raises serious questions about the reserves currently available.

Rising political uncertainty in the United States is another reason for the increase in demand for gold. Switzerland's largest financial holding company, UBS, which offers a wide range of financial services worldwide, recently warned its clients to buy safe assets such as gold if the presidential election is difficult, which could lead to a decline in the stock market. caused irritability (Figure 2). 


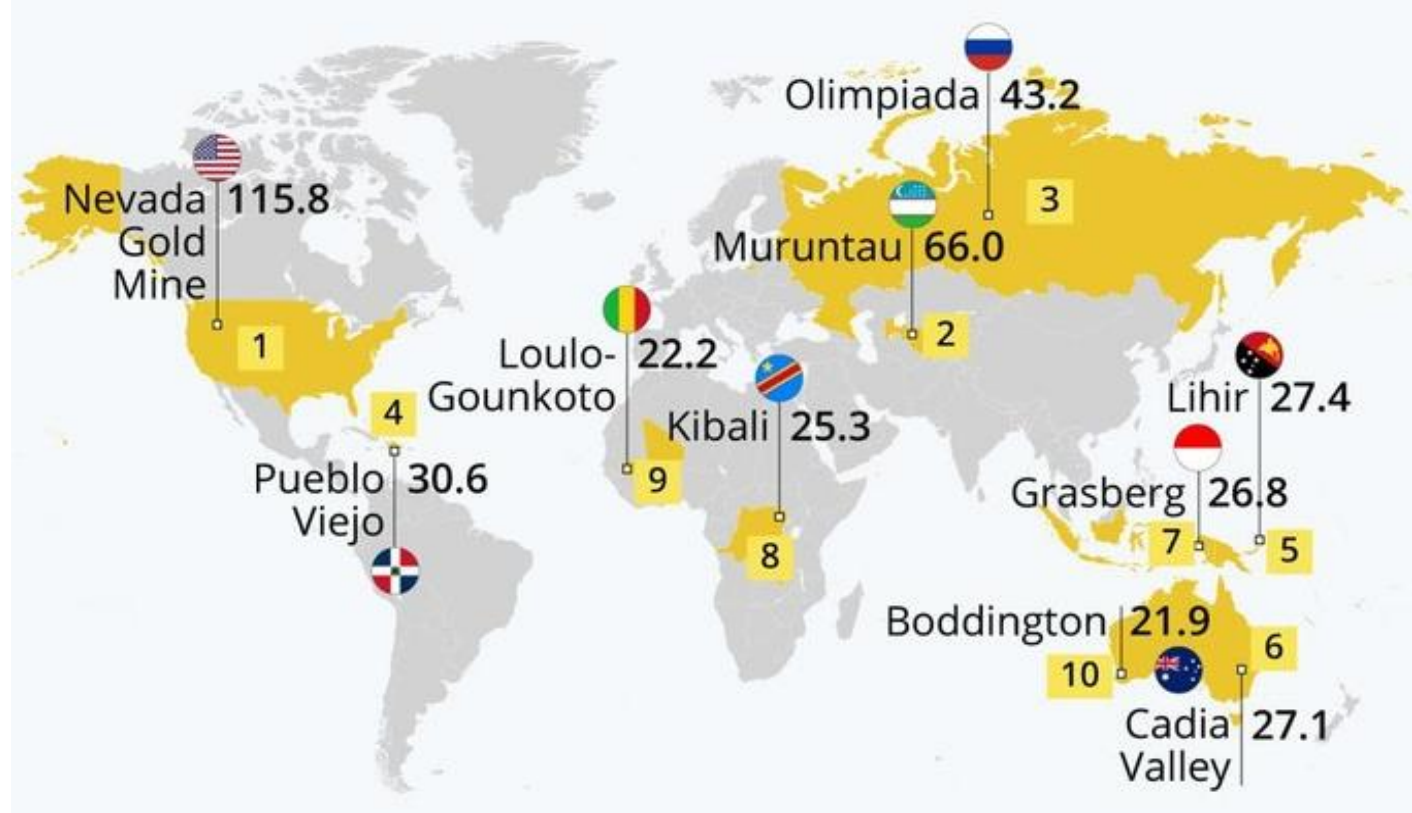

Figure 2. The largest gold mines in the world.

The level of demand for the precious commodity now raises serious questions as to whether world gold reserves are declining [4]. Indeed, according to some experts, the world has reached the peak of gold production, while annual production has largely stabilized in recent years.

China tops the list of countries with the largest gold production in 2020. Uzbekistan will produce 101.6 tons of gold in 2020. With this indicator, the republic ranks 8 th in the world for the extraction of precious metals.

Gold is one of the most unique elements in the world. According to the World Gold Council (WGC), 3.478 tons (122.7 million ounces) of gold were mined in 2020. This figure has been declining for two years in a row.

At the same time, the discovery of gold deposits with huge resources is declining from year to year. For example, the Republic of
South Africa produced more than 1.000 tons of gold in 1970 and was the world's leading country, but last year it dropped out of the Top 10 League of Best Gold Miners.

Uzbekistan ranks 16 th out of 132 countries in terms of state gold reserves, with 332.5 tons of gold reserves. This was reported by the World Gold Council [5].

According to the report, in 2020, Uzbekistan's gold reserves will decrease by 3.4 tons.

Kazakhstan has the largest gold reserves in Central Asia, ranking 14th with 387.9 tons of gold.

Tajikistan is 62nd and Kyrgyzstan is 63rd. No information is provided on Turkmenistan.

According to the Council, at the beginning of 2021, the world's monetary gold reserves amounted to 35.244 thousand tons. 
The United States has the largest gold reserves in the world, with more than 8.1 thousand tons. Germany, Italy, France, Russia, China, Switzerland, Japan, India, and the Netherlands are also in the top ten. It is in second place with 66 tons.

The Olympic mine in Russia was discovered in 1975 in the North-Yenisei region and has the third largest production capacity in the world with a production capacity of 43.2 tons per year [6].

As Spot previously wrote, it is planned to increase gold and silver production by 150 tons in 2020 and 300 tons in 2021 (Figure 3).

In recent years, information about valuable minerals in Uzbekistan has been gradually disclosed. In March, the central bank announced the volume of gold exports when it became known that $70-80$ tons of gold are exported annually. This year, for example, it is planned to sell 80 tons.

Our country is one of the leaders not only in the mining industry but also in the export of precious metals. Thus, in July, Uzbekistan became the absolute leader in gold sales [7].

The country sold 11.6 tons. Mongolia is in second place (6.1 tons). Small volumes ( 0.5 tons each) were sold by Russia and Germany.
As Spot previously wrote, the high price of gold has partially offset Uzbekistan's losses due to the pandemic.

In 2020, the country mined more than 100 tons of gold for the first time and ranked 8th in the ranking between Brazil and Mexico.

Uzbekistan is among the top ten countries in the world in terms of gold production and ranks 8 th. This was reported by Forbes based on data from the World Gold Council (WGC).

The first place in this ranking was taken by China, which in 2020 produced 368.3 tons of gold. The second place was taken by Russia (331.1 tons), the third by Australia (327.8 tons). The United States (190.2 tons), Canada (170.6 tons), Ghana (138.7 tons), Brazil (107 tons), Mexico (101.6 tons), and Indonesia (100.9 tons) round out the top ten [8].

It is noted that in 2020, world gold production amounted to 3478.1 tons (122.7 million ounces). After steady growth over the past few years, these numbers have declined slightly for the second year in a row. The main reasons for this are the coronavirus pandemic and the reduction of the search budget [9]. 


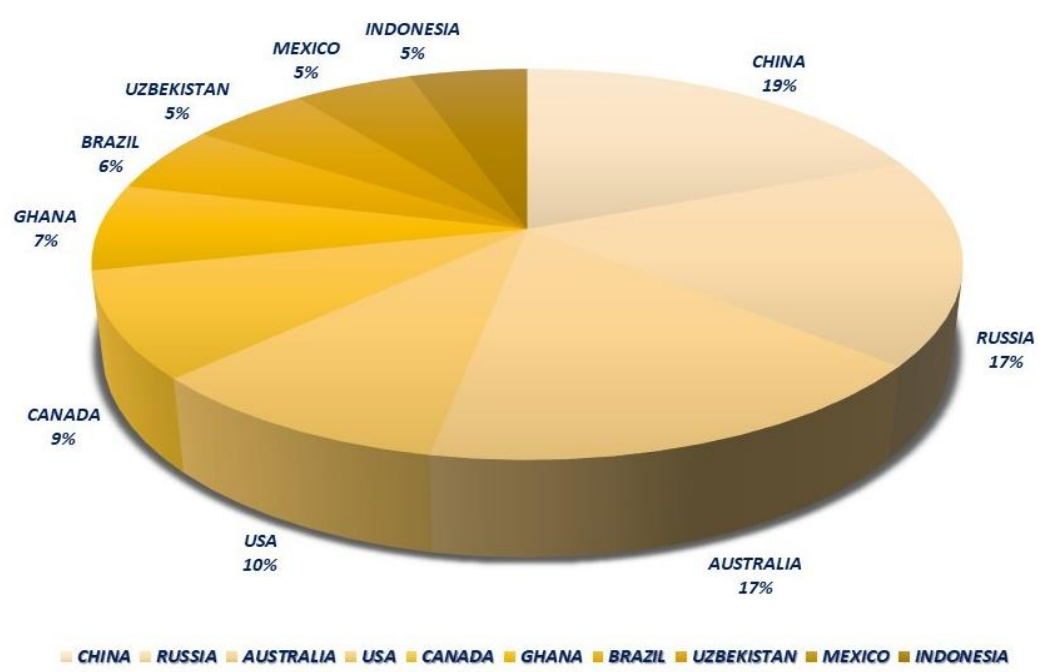

Figure 3. Top 10 countries for gold mining in 2020

For the second year in a row, the Muruntau deposit in Uzbekistan has become the world's largest gold producer.

Last year, Kitcho estimated that the Muruntau deposit produced about 2 million ounces (56.7 tons) [10].

"With a vast resource base of more than 150 million ounces, Muruntau may retain its title as the world's largest gold mine in the near future", analysts said.

The Muruntau deposit was discovered in 1958 by Soviet geophysicists Yuri Mordvintsev and Petr Khramishkin. Industrial gold mining here began in 1969.

The second place was taken by the American Carlin deposit, which last year produced 1.6 million ounces (45.4 tons) of precious metals. It should be noted that in 2020, the mine entered the top ten, which managed to increase gold production by $27 \%$.

The third place in the ranking was taken by the Russian "Olympic" mine. It produced 1.2 million ounces ( 34 tons) in 2020, which is $14 \%$ less than in 2019 [10].

It should be noted that gold is the main export product of Uzbekistan. Its share in 2020 was $44 \%$ of Uzbekistan's exports (35\% in 2019).

Previously, there was no official data-the deposit was always estimated.

According to a recent company report, Kitcho, a Canadian precious metals retailer, did not include Muruntau in its list of the world's largest gold miners [11].

Kitcho explained this by citing the lack of information about the mine. Official data was not available before, but the company estimated Muruntau based on estimates.

For example, at the end of 2020, about 56.7 tons ( 2 million ounces) of gold were mined at the Kitco deposit, according to external estimates, primarily Muruntau. The deposit's resource base is estimated at more than 4,000 tons (150 million ounces).

Thus, in March, the Central Bank for the first time released statistics on gold sales from 2010 
to 2020. It turned out that Uzbekistan has sharply increased metal exports in recent years.

The State Statistics Committee regularly publishes information on how much the country earns from gold sales, but data on reserves and production are still based on external accounts.

Earlier, Uzbekistan was among the top 10 countries in the world for gold mining. Then the source, according to the World Gold Council, according to which in 2020 the country was the first to extract more than 100 tons of gold (101.6 tons). As a result, he rose to eighth place in the Peruvian rankings.

In the U.S., Forbes then noted that the country had the world's largest open-pit gold deposit, Muruntau, with huge deposits of turquoise and arsenic. The publication acknowledged that the mine is the largest gold reserve in the world.

The resolution signed by the President on June 8, 2020, "On measures to organize the activities of the University of Geological Sciences in the system of the State Committee for Geology and Mineral Resources", addresses the existing problems related to training and retraining.

According to the Decree of the President, the University of Geological Sciences was established under the auspices of the State Geological Committee, specializing in the integration of education, research, and practice in the field of geology.

The main tasks and activities of the university are:

- Training of highly qualified and modernminded personnel with higher education in accordance with international educational standards;

- Development and implementation of modern educational programs and forms, use of advanced pedagogical and information technologies, and incorporation of the most recent scientific and technological achievements into the educational process;

- Improving the quality of training of specialists and research and teaching staff on the basis of the principle of continuity and continuity of science and education;

- Wide involvement of talented students in fundamental, practical, and innovative projects; the introduction of effective incentives for them;

The development of clear criteria and effective mechanisms for the commercialization of scientific developments in the field of earth sciences; the widespread introduction of their results in the practice of geology;

- Development and strengthening of longterm cooperation with leading educational institutions, research centers, business communities, and international geological societies of foreign countries;

- Retraining and advanced training of geologists, etc.

The University is a specialized higher education and research institution of the Republic for the State Geological Committee, mining enterprises, and other sectors of the economy, training qualified personnel in the field of geology and conducting research;

The University includes the Institute of Geology and Geophysics, named after H.M.Abdullayev, the Institute of Mineral Resources, the Institute of Hydrogeology and Engineering 
Geology, the Institute of Geology and Exploration of Oil and Gas Fields, the Institute of Geology and Retraining, and the State Geological Museum;

Students are admitted to the university on the basis of a state order and a fee-based contract, based on the parameters of admission to higher educational institutions in the republic, which are formed on the orders of the State Geological Committee and approved annually;

Applicants can apply to the university from the 2020-2021 academic year in the prescribed manner.

On the basis of state educational standards in the Republic of Uzbekistan, students study in accordance with the agreements reached with the leading foreign higher education institutions in the fields of geology and mining, including the joint educational programs of St. Petersburg Mining University (Russian Federation). is expected [12].

\section{CONCLUSION}

Geological study of the economic and economic geology of the Republic of Uzbekistan: mineral deposits, stolen deposits in the world, unprecedented development of economic geology and the state economy. Its contribution is considered. In addition, the establishment of the University of Geological Sciences in the development of economic geology in the Republic of Uzbekistan and the introduction of the direction of the economics of geological prospecting will contribute to the development of this field.

\section{REFERENCES}

1. Walter L. Pohl. Economic geology. Principles and practice. Metals, minerals, coal and hydrocarbons - Introduction to formation and sustainable exploitation of mineral deposits. 2nd revised edition. Schweizerbart Science Publishers. Stuttgart-2020. Germany. P. 755.

2. https://www.encyclopedia.com/science/ne ws-wires-white-papers-and-

books/economic-geology

3. Economic Geology. University of Alberta, 2021.

https://www.ualberta.ca/science/economi c-geology.html

4. Atlas of stones, minerals and textures (website).

http://www.geosci.unc.edu/Petunia/lgMet Atlas/mainmenu.html.

5. Bates, Robert Latimer. Industrial minerals: how they are found and used. Hillside, $\mathrm{NJ}$ : Enslow Publishers, 1988.

6. McGraw-Hill Encyclopedia of Science and Technology. 8th. New York: McGraw-Hill, 1997.

7. https://kun.uz/35849035; https://kun.uz/news/2021/05/03/eng-kopoltin-zaxirasiga-ega-mamlakatlar-reytingielon-qilindi

8. Uzbekistan has entered the top 10 countries of the world in gold mining. 24.06.2021. A source: uznews.uz. https://telegra.ph/Uzbekistan-voshel-vtop-10-stran-mira-po-dobyche-zolota-0624.

9. The largest gold deposits in the world and Uzbekistan: Muruntov in the leading position

https://www.spot.uz/ru/2020/09/30/gold/ https://www.spot.uz/media/img/2020/09/0 Likbx16014452069081_b.jpg

10. Due to insufficient data, Muruntov was not included in the largest gold deposits 2021th Year 3 September, 14:40 economy 
https://www.spot.uz/ru/2021/09/03/murun tau/

11. Vladimir Basov. The world's top 10 biggest gold mines in 2020 - report. 05.03.2021. https://www.kitco.com/news/2021-03-

05/The-world-s-top-10-biggest-gold-minesin-2020-report.html

12. Pirnazarov M.M., Isakov M.U., Aripov Sh.P., 2020 Investment attractiveness and evaluation system of mineral resources of the Republic of Uzbekistan taking into account international experience. Mining Bulletin of Uzbekistan, No. 2 (81) 2020. 41$44 \mathrm{p}$.

13. Isokov, M. U., Maripova, S. T., \& Movlanov, J. J. (2020). MODELING REGULARITIES OF LOCATION AND FORMATION CONDITIONS OF THE GOLD MINING OF THE SOUTH TIAN-SHAN. PalArch's Journal of Archaeology of Egypt/Egyptology, 17(6), 3717-3733.

14. Koloskova, S. M., \& Movlanov, J. J. STATISTICAL REGULARITIES OF THE LOCATION OF GOLD OBJECTS IN THE DOMESOZOIC STRUCTURAL AND FORMATION COMPLEXES OF UZBEKISTAN.

15. Koloskova, S. M., \& Movlanov, J. J. STATISTICAL REGULARITIES OF THE LOCATION OF GOLD OBJECTS IN THE DOMESOZOIC STRUCTURAL AND FORMATION COMPLEXES OF UZBEKISTAN.

16. KOLOSKOVA, S., \& MOVLANOV, J. (2019). Typomorphic features of the quartz of various mineral paragenesis from the gold mineralization in Karakshatau Mountains (West Uzbekistan). Bulletin of the Mineral Research and Exploration, 159(159), 117-127.

17. KOLOSKOVA, S., \& MOVLANOV, J. (2019). Typomorphic features of the quartz of various mineral paragenesis from the gold mineralization in Karakshatau Mountains (West Uzbekistan). Bulletin of the Mineral Research and Exploration, 159(159), 117-127. 